University of Nebraska - Lincoln

DigitalCommons@University of Nebraska - Lincoln

Faculty Papers and Publications in Animal

Science

Animal Science Department

January 1973

\title{
Reproductive efficiency and viability in two Bos indicus and two Bos taurus breeds in the tropics of India and Colombia
}

L. (Lemka) Hamed

University of Georgia, Athens

R. E. McDowell

Cornell University

L. Dale Van Vleck

University of Nebraska-Lincoln, dvan-vleck1@unl.edu

H. Guha

Directorate of Animal Husbandry, West Bengal, Calcutta-I, India.

J. J. Salazar

Departmento de Ciencias Animales, Instituto Colombiano Agropecuario, Bogota, Colombia.

Follow this and additional works at: https://digitalcommons.unl.edu/animalscifacpub

Part of the Animal Sciences Commons

(Lemka) Hamed, L.; McDowell, R. E.; Van Vleck, L. Dale; Guha, H.; and Salazar, J. J., "Reproductive efficiency and viability in two Bos indicus and two Bos taurus breeds in the tropics of India and Colombia" (1973). Faculty Papers and Publications in Animal Science. 332.

https://digitalcommons.unl.edu/animalscifacpub/332

This Article is brought to you for free and open access by the Animal Science Department at DigitalCommons@University of Nebraska - Lincoln. It has been accepted for inclusion in Faculty Papers and Publications in Animal Science by an authorized administrator of DigitalCommons@University of Nebraska - Lincoln. 
Lemka, L., R. E. McDowell, L. D. Van Vleck, H. Goha, and J. J. Salazar. 1973. Reproductive efficiency and viability in two Bos indicus and two Bos taurus breeds in the tropics of India and Colombia. Journal of Animal Science 36:644-652.

Abstract: Records from two herds in India and two in Columbia representing respectively two breeds of Bos indicus (Hariana and Deshi) and two Bos taurus breeds-Blanco Orejinegro (BON) and Costeño Con Cuernos (CCC) were evaluated for breeding efficiency and viability. Average age at first calving was 52.1, 46.3, 39.5 and 40.7 months for Hariana, Deshi, CCC and BON. Season of birth did not influence age at calving. Ranking for calving interval was similar, average 479, 418, 396 and 382 days with season effects significant ( $\mathrm{P}<.05)$ for only Deshi. BON and CCC had fewer days open but much shorter lactation periods, average 73 and 157, thus days carried calf in lactation were similar for all breeds. Percent of time dry per calving interval was high for all breeds, 44.2, 36.7, 64.1 and 81.0 for Hariana, Deshi, BON and CCC. Average annual mortality of females by 12 months of age was $23.6 \%$ for Hariana, $17.0 \%$ Deshi and $27.0 \%$ BON. In the same herds $46.4 \%, 51.1 \%$ and $49.0 \%$ of females born alive lived to first calving and annual losses among cows were $18.0 \%, 17.0 \%$, and 21.0\%; therefore, affording little opportunity for selection among females. Temperament, as determined by response to the milking process with and without the calf present, showed all the breeds were similar in this respect. Environmental effects were most important for all traits but genetic differences were indicated for age at first calving and milk yield. On a theoretical basis little gain could be expected in net dairy merit from crosses between the Columbian and Indian breeds.

Copyright ${ }^{\odot} 1973$ American Society of Animal Science. Used by permission. 


\title{
REPRODUCTIVE EFFICIENCY AND VIABILITY IN TWO BOS INDICUS AND TWO BOS TAURUS BREEDS IN THE TROPICS OF INDIA AND COLOMBIA
}

\author{
L. Lemka, ${ }^{1}$ R. E. McDowell, L. D. Van Vleck, H. Guha ${ }^{2}$ and J. J. Salazar ${ }^{3}$ \\ Cornell University, ${ }^{4}$ Ithaca, New York 14850, Central Livestock Research-cum- \\ Breeding Station, Haringhata and Instituto Colombiano Agropecuario, Turipaná
}

\section{Summary}

$\mathbf{R}$ ECORDS from two herds in India and two in Columbia representing respectively two breeds of Bos indicus (Hariana and Deshi) and two Bos taurus breeds-Blanco Orejinegro (BON) and Costeño Con Cuernos (CCC) were evaluated for breeding efficiency and viability. Average age at first calving was $52.1,46.3,39.5$ and 40.7 months for Hariana, Deshi, CCC and BON. Season of birth did not influence age at calving. Ranking for calving interval was similar, average $479,418,396$ and 382 days with season effects significant $(\mathrm{P}<.05)$ for only Deshi. BON and CCC had fewer days open but much shorter lactation periods, average 73 and 157 , thus days carried calf in lactation were similar for all breeds. Percent of time dry per calving interval was high for all breeds, 44.2, 36.7, 64.1 and 81.0 for Hariana, Deshi, BON and CCC. Average annual mortality of females by 12 months of age was $23.6 \%$ for Hariana, $17.0 \%$ Deshi and $27.0 \%$ BON. In the same herds $46.4 \%, 51.1 \%$ and $49.0 \%$ of females born alive lived to first calving and annual losses among cows were $18.0 \%, 17.0 \%$, and $21.0 \%$; therefore, affording little opportunity for selection among females. Temperament, as determined by response to the milking process with and without the calf present, showed all the breeds were similar in this respect. Environmental effects were most important for all traits but genetic differences were indicated for age at

\footnotetext{
1 Present address: Department of Biochemistry, University of Georgia, Athens. (Now Mrs. Linda L. Hamed).

2 Present address: Directorate of Animal Husbandry, West Bengal, Calcutta-1, India.

8 Present address: Departmento de Ciencias Animales, Instituto Colombiano Agropecuario, Bogota, Colombia.

4 Department of Animal Science.
}

first calving and milk yield. On a theoretical basis little gain could be expected in net dairy merit from crosses between the Columbian and Indian breeds.

\section{Introduction}

As attempts are made to improve the productivity of cattle in tropical regions for milk production, it becomes increasingly clear that the genetic potential of many breed groups for this purpose is extremely limited. Among their chief disadvantages are late ages at sexual maturity and long calving intervals, both very commonly reported. Although this contrasts with the performance of European Bos taurus breeds kept in temperate climates, crosses between European and Zebu stock have frequently shown a decline in reproductive efficiency under tropical conditions. A possible solution, not yet explored, is the use of the Bos taurus breeds which, after up to five centuries of acclimatization, are now considered native to certain tropical regions. This seems particularly attractive since their reproductive efficiency and rates of maturity appear to be reasonably comparable with those of temperate zone cattle as reported by Bodisco and Mazzari, 1962; de Alba and Carrera, 1958; Pearson et al., 1968; Rios and Bodisco, 1962, and superior to those of Zebus, at least in comparisons between meat producing types (e.g., Stonaker, 1971; Plasse $e t$ al., 1968). Unfortunately, there are no existing sources of data from which tropical Bos taurus and Zebu cattle, kept together, may be compared for milk production. Conclusions based on records of the two types in separate locations must be obviously tentative, nevertheless, some information can be derived 
which can serve at least for broad screening of indigenous stocks. This paper attempts to assess the productivity of two breeds of each type, tropical Bos taurus and Bos indicus, with the objective of determining whether there are characteristics of the former which might be used with advantage in the improvement of the Zebu.

\section{Materials and Methods}

The data came from four herds, two of Bos indicus and two of Bos taurus.

The herd of Hariana (Bos indicus) was at the Central Livestock Research-cum-Breeding Station, Haringhata, India where the climate varies from cool to hot with medium to high humidity (table 1). Data included 3,616 calvings for 1,136 cows from 1952 to 1966 , and viability of 2,693 female calves and 2,641 male calves. The feeding and management practices and general performance for this herd were reported by Ngere et al. (1973). The Hariana is a dual purpose breed -draft and milk-with mature females averaging 350 kilograms body weight.

The Deshi herd (Bos indicus) was also at Haringhata but maintained as a separate herd. There were 1,405 calvings for 336 cows during the period 1957 to 1966 . The origin, phenotypic characteristics and milk yield for this herd were reported by Moulick et al. (1972). Deshi is one of the smallest of Indian breeds, mature females average 200 kilograms.

The Costeño Con Cuernos (CCC), Bos taurus type, was at the Instituto Columbiano Agropecuario, Turipaná. This breed is of Mediterranean origin but has been in Colum- bia since the 1500's (Pinzon et al., 1954). Its main habitat is the Sinu river valley, a hot, humid area of north-central Columbia (table 1). The size of mature females is 350 to 380 kilograms. Data included 936 calvings for 443 cows from 1959 to 1964.

The Blanco Orejinegro (BON) herd (Bos taurus) was kept at the Instituto Columbiano Agropecuaria, El Nus. This breed is found in the intermediate elevations of the Columbian Andes where temperature conditions are warm to hot and a long wet season (table 1). The BON resembles the Wild White cattle of Britain and some postulate they originated from Britain, but Pearson (1968) traced their origin to introductions from Spain. They are about equal in size to the CCC. The data included 1,357 calvings for 510 cows for the period 1957 to 1965 . The feeding and management practices and general performance for the BON herd have been described by Pearson et al. (1968).

The format for compiling records was standard for all herds with minor variations. The Hariana and Deshi herds had identifiable divisions of cows purchased as foundation stock from local villages, and station born. Those identified as foundation cows in the CCC herd were transferred from a discontinued government farm near Turipaná. The BON herd had existed as a closed herd for a number of years.

Herd Management. The Indian herds were stall fed post first calving with green chopped forages or paddy straw plus concentrates. The Columbian herds were grazed on native grass pastures continusously and fed $1 \mathrm{~kg}$ of concentrate at each milking. The Hariana and

TABLE 1. METEROLOGICAL DATA FOR HARINGHATA, INDIA AND EL NUS AND TURIPANÁ, COLOMBIA

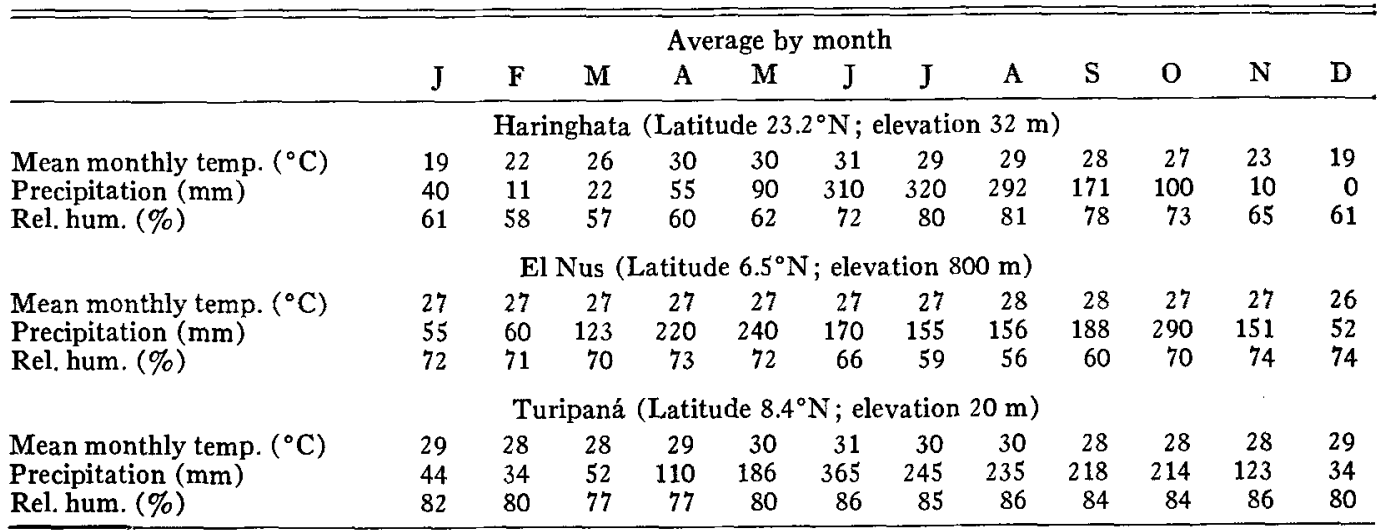


Deshi were milked with the calf present. The BON cows were for the most part milked without calves present. In the CCC herd milking was for the most part with the calf present but during some periods calves were separated at birth.

In the Indian herds first breeding occurred at first estrus for both heifers and cows. The Indian cattle were bred by AI or natural service following visual heat detection or with vasectomised bulls. In the $\mathrm{CCC}$ and $\mathrm{BON}$ herds all breeding was by natural service, either hand mating or pasture breeding. Heifers were serviced at first estrus following 18 months and cows at the third estrus following parturition.

Seasons were divided according to rainfall and temperature. For Columbia, the dry season was December through March (table 1). Three seasonal groupings were used for India -winter, November through February; summer, March through June; and monsoon, July through October.

The data used were determined as follows:

Age at first calving (months); date of first calving minus date of birth.

Calving interval; days between dates for successive lactations, exclusive of abortions.

Days open: Hariana and Deshi herds, date of conception minus date of parturition; $\mathrm{CCC}$ and BON herds, calving interval minus standard gestation period of 280 days.

Lactation length; date of parturition + 300 days unless record indicated milking ceased earlier.
Number of lactations completed; sum of gestations where there were records of attempts to milk the cows.

Days dry; calving interval minus days in lactation.

Viability; percentage of animals born reaching designated age.

\section{Results and Discussion}

Age at First Calving. The difference between the means for Columbian and Indian breeds for age at first calving (table 2) was large. Milk yields were above average for cows'during seasons most favorable for forage production (wet and monsoon), thus more milk was available for calves born during these seasons. Better feeding in the early months could have influenced age of sexual maturity. However, there were no significant differences in means for age at first calving due to season of birth (table 2). No doubt the intervening seasonal fluctuations in feed supplies and other factors masked any effect of better nutrition in the early months of life. This agrees with findings on N'Dama cattle in Sierra Leone where season of birth influenced weaning weight but weaning weight was not related to age of first calving (Touchberry, 1967).

The distribution of ages at first calving in figure 1 are near normal for the two Colombian breeds, but not so in the Indian breeds. The early age of calving $\quad<30$ months) for some females in the BON and $\mathrm{CCC}$ herds indicates these breeds may reach

TABLE 2. MEANS AND STANDARD DEVIATIONS FOR AGE AT FIRST CALVING, CALVING INTERVAL AND DAYS OPEN OF THE VARIOUS BREEDS

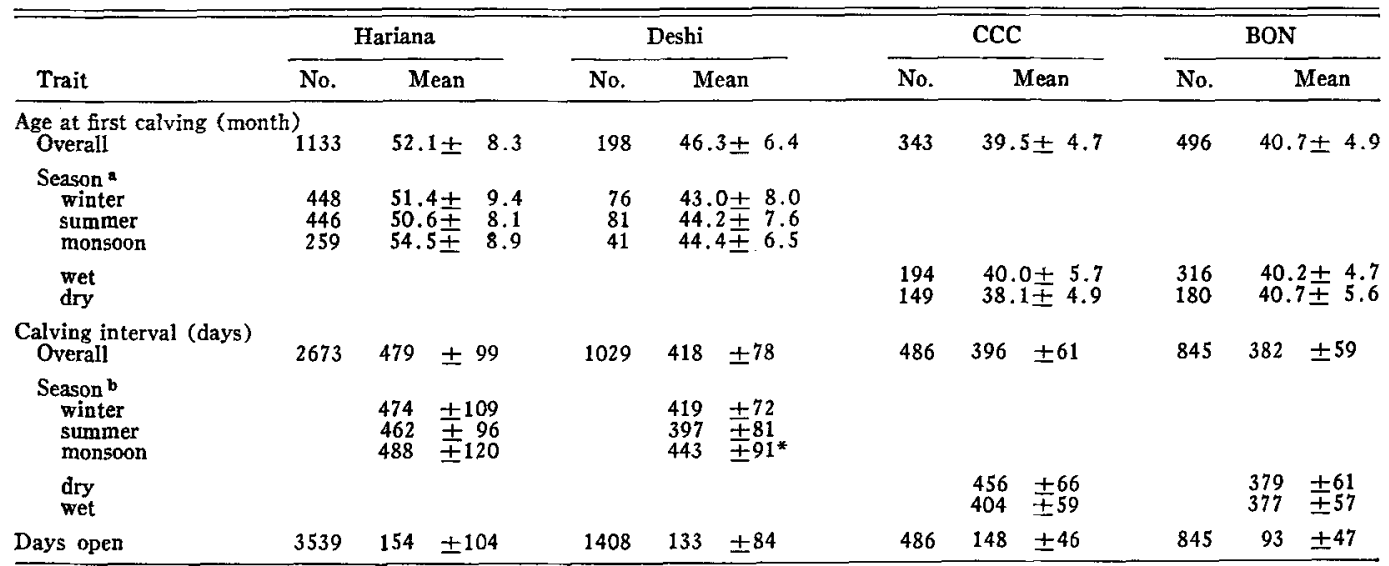

* Significantly different from ineans for other seasons $(P<.05)$.

* Based on season of birth.

season when calving occurred. 


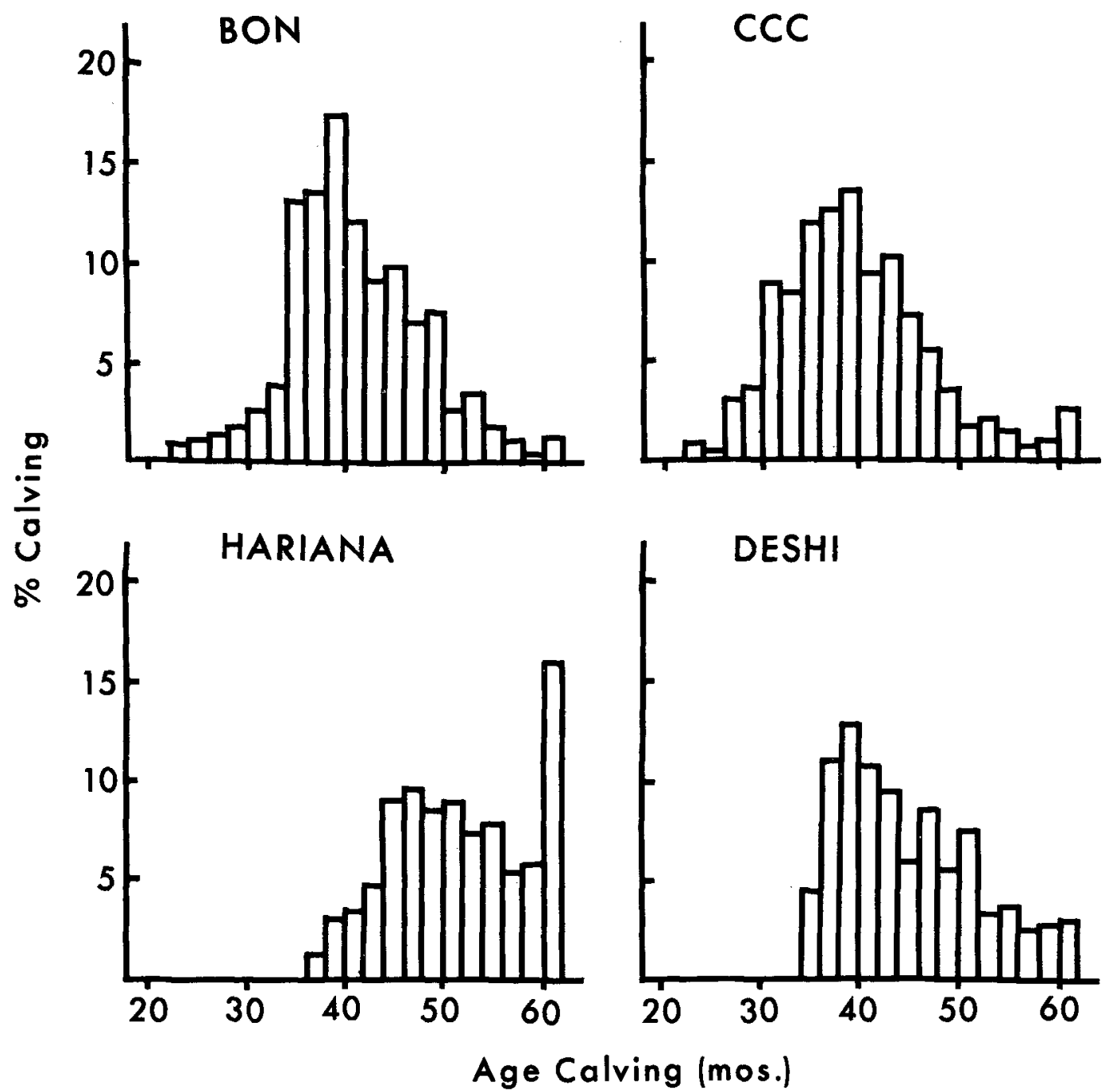

Figure 1. Distribution of age at first calving by 2 month intervals for four breeds.

puberty early enough for breeding to calve at ages corresponding to those acceptable in most U.S. dairy herds. None of the Indian cattle calved earlier than 36 months, even though breeding was commenced at the first observed estrus, suggesting Deshi and Hariana reached sexual maturity later than the Colombian breeds. Although the climatic conditions prevailing at Haringhata (table 1) are on the whole not as severe as for Turipaná, Colombia (CCC herd), environmental effects, including nutrition, were no doubt important in rate of development. Still, the implication that genetic effects may be involved is supported by tests made in India which showed that the mean for age of first estrus for three Indian breeds could only be lowered from 26 months to 20 months by high levels of feeding (McDowell, 1972). Under good feeding conditions in the U.S. average age for first estrus in Red Sindhi (Bos indicus) females exceeded 20 months. In Red SindhiJersey crosses age of first estrus was delayed when the proportion of Red Sindhi breeding exceeded $50 \%$ (McDowell, Fletcher and Johnson, 1959).

Whether the difference in age at first calving for Deshi and Hariana is genetic or environmental is not discernible. Since the Deshi is a very small breed, it is possible that the feeding regime at Haringhata permitted their more nearly approaching their potential for growth rate than the larger Hariana. 
Calving Interval. There were large differences among the breeds for calving interval (table 2). The average of 463 days for Deshi and Hariana falls within the range of previous reports for Bos indicus breeds in India (Mahadevan, 1966; Tomar, 1965). The overall mean for BON and CCC of 399 days is in keeping with values reported for temperate zone herds (Miller, Van Vleck and Henderson, 1967), and 28 days less than for Holsteins kept at higher elevations in Colombia (Salazar et al., 1970).

The repeatability estimates for calving interval of $.12, .10,-.30$ and .10 for Hariana, Deshi, CCC and BON indicate little variation associated with genotype for this trait. The correlations for calving interval with subsequent lactation length and milk yield were low and nonsignificant ( -.01 to .13). Year effects were significant $(\mathrm{P}<.05)$ for calving interval in Hariana and $\mathrm{CCC}$ but nonsignificant in the other two breeds. Only the Deshi showed significant $(P<.05)$ effects of season of calving on calving interval (table 2). On the premise that poorer breeding efficiency may have been tolerated in the early stage of herd development, calving intervals for foundation and farm born cows were examined, but differences were small and nonsignificant. The average interval for 739 calvings of foundation cows in the Hariana herd was 472 days and 482 days for 1,934 calvings of farm born cows. For the CCC herd the means were similar, 397 days for foundation and 395 for station born.

Length of gestation would have contributed little to the differences in calving interval among herds. The means were 285, 287, 280 and 281 days for Deshi (Moulick et al., 1972), Hariana (Ngere et al., 1972), BON and CCC (McDowell, 1971). As indicated by several reports (McDowell, 1971; Moulick et al., 1972; Ngere et al., 1973; O. Syrstad, personal communication) suckling may have contributed to the differences among breeds for calving interval. The BON had the shortest intervals and were usually milked without calf. In the CCC herd, cows milked with calf at foot averaged 443 days, while those milked without calf averaged 389 days. In the Hariana and Deshi herds calving interval was somewhat shorter when calves died early in lactation but so was the duration of lactation. Method of heat detection may have also been a factor.

Variation in lactation length could have contributed to differences in calving interval. The BON cows had the least days open (table 2) but the average number of days of pregnancy during lactation was no higher than for the other three breeds. The conclusion is that differences between Bos indicus and Bos taurus are indicated in breeding efficiency as expressed by calving interval and days open, but before these differences can be assumed to be genetic, comparisons would have to be made with a uniform system of heat detection and standard length of lactation.

Lactation Length. The average duration for lactations 300 days or less was much greater for the Indian breeds than for the Colombian breeds (table 3 ); however, as indicated by the standard deviations, lactation length was highly variable in the BON and CCC breeds.

The BON and CCC compared favorably in milk yield per day of lactation with Hariana (table 3), but when expressed as kilogram per day of calving interval the BON was poorest. The Indian cattle were milked until they produced less than $.25 \mathrm{~kg}$ of milk per day while the BON and CCC were dried off at higher levels, although the truncation points were not indicated in the records.

Even though the Colombia herds had shorter calving intervals, the short length of lactation resulted in their being dry 64 to $81 \%$ of the time (figure 2).

Viability. Pre-calving losses of females in

TABLE 3. MEANS AND STANDARD DEVIATIONS FOR LACTATION LENGTH, MILK YIELD AND TIME DRY

\begin{tabular}{lcccc}
\hline Trait & Hariana & Deshi & CCC & BON \\
\hline No. records & 995 & 244 & 340 & 494 \\
Milk yield (kg) & & & & \\
$<300$ days & $861 \pm 386$ & $424 \pm 173$ & $481 \pm 226$ & $221 \pm 348$ \\
per day of lactation & 3.2 & 1.6 & 3.1 & 3.0 \\
per day of calving int. & 1.8 & 1.0 & 1.2 & 0.6 \\
Lactation length (days) & $267 \pm 66$ & $265 \pm 75$ & $157 \pm 108$ & $73 \pm 81$ \\
Time dry/calving int. (days) & $203 \pm 121$ & $141 \pm 62$ & $258 \pm 173$ & $303 \pm 107$ \\
Time dry/calving int. (\%) & 44.2 & 36.7 & 64.1 & 81.0 \\
\hline
\end{tabular}




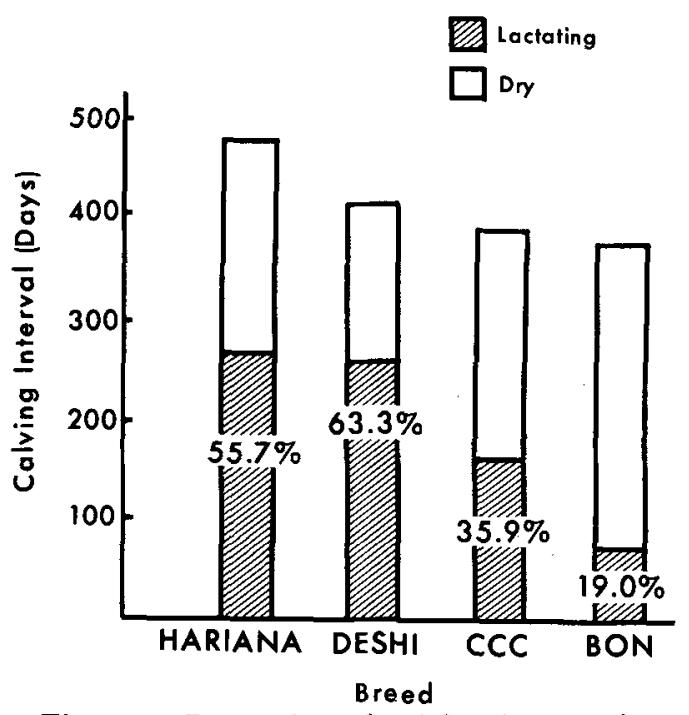

Figure 2. Proportion of calving interval in lactation for four breeds.

the Hariana, Deshi and BON herds are given in table 4. Mortality up to 12 months of age was rather high. Year effects were important due to epidemic losses resulting from outbreaks of foot and mouth disease in the India herds or other major diseases, such as anaplasmosis in the BON herd. The influence of season of birth on mortality was unimportant in the Deshi and Hariana herds. Effects of sex were significant in the Hariana herd as $18.3 \%$ of all female calves born alive died prior to reaching 6 months of age while only $15.6 \%$ of the males died prior to 6 months. The reason for sex differences is not discernible. Generally, higher value is placed on males for agricultural power than for females as milking stock, thus the personnel handling the calves may have given preferential treatment to males.

Most studies have considered mortality as constituting total losses prior to first calving but in this study the proportion of females sold (table 4) was included in the overall estimate of viability since the majority were removed due to unthriftiness following health problems, failure to conceive, or the dams were extremely poor milkers.

Assuming about $50 \%$ of the females born alive in these three herds lived long enough to produce at least one calf, 1 to $3 \%$ of all female foetuses were born dead or terminated in abortions, and a sex ratio of 47 to $49 \%$ females (Hariana herd $48.9 \%$ females), approximately $25 \%$ of the total females born alive contributed future progeny that came into lactation. If involuntary culling of cows is in the range of 15 to $20 \%$ (table 4), the opportunity for selection of females is less than $10 \%$. The usual practice is to remove only those cows which refuse to milk (Pearson et al., 1968) and cows which will not rebreed by 400 to 600 days post-calving (Ngere et al., 1973).

Data were incomplete for the CCC herd but female calf mortality up to 12 months of age was $23.9 \%$; therefore, it is likely that no higher proportion lived to calve than in the other herds.

Whether the viability of young stock in the four herds has a genetic link cannot be determined. It may be that such mortality is inevitable with local management practices and that any breed subject to similar treatment would have responded in the same fashion or even worse. There may be some basis for assuming genetics are involved since losses among crossbreds in three of the herds were less than for purebreds (McDowell, 1971; Moulick et al., 1972; Ngere et al., 1973).

Temperament. This is a trait that is difficult to characterize objectively. Branton, McDowell and Brown (1966) described it as "standing to milk". Using this definition they concluded that temperament would be a serious deterrent to the usefulness of Zebu-European breed crosses for dairying in the U.S. McDowell (1971) reached the same conclusion about the dairy temperament of a local Zebu breed (Horro) in Ethiopia. These conclusions were based on milking without the calf present. Docility is even more difficult to assess in herds milked with calf because one is never certain whether the main purpose of the calf's presence is to soothe the cow or promote milk-let-down. The BON herd was milked almost entirely without calves and success in the CCC herd, at least part of the time, suggests these breeds may be more re-

\begin{tabular}{|c|c|c|c|}
\hline Measure & Hariana & Deshi & $\mathrm{BON}$ \\
\hline Jo. born & 2578 & 509 & 221 \\
\hline $\begin{array}{l}\text { bied }<12 \text { months }(\%) \\
\text { bold } 12 \text { months to }\end{array}$ & 23.6 & 17.0 & 27.0 \\
\hline $\begin{array}{l}\text { 1st calving (\%) } \\
\text { Cotal losses birth to }\end{array}$ & 22.8 & 26.9 & \\
\hline $\begin{array}{l}\text { 1st calving }(\%) \\
\text { Cow losses/year }(\%)\end{array}$ & $\begin{array}{l}46.4 \\
18.0\end{array}$ & $\begin{array}{l}51.1 \\
17.0\end{array}$ & $\begin{array}{l}49.0 \\
21.0\end{array}$ \\
\hline
\end{tabular}

a Due to disease, physical injury, calf died and cow refused to milk or extremely low production. 
sponsive to the presence of milkers than the Indian breeds.

In the BON herd there was no milk recorded for $4.3 \%$ of the calvings and in over $45 \%$ of the lactations milk yield was less than $100 \mathrm{~kg}$. For the CCC, no milk was recorded for $22.8 \%$ of the calvings. The CCC cows milked with calf averaged $701 \mathrm{~kg}$ milk per lactation as compared to $322 \mathrm{~kg}$ for those milked without calf (McDowell, 1971); however, there was some confounding with lactation number as the latter consisted principally of first lactations. In spite of lower yields without the calf present, Salazar and Waugh (1968) concluded that CCC cows were docile enough to be milked without calf. Pearson $e t$ al. (1968) also noted the general docility of the BON. de Alba and Carrera (1958) found that in Criollo (Bos taurus) type cattle in Costa Rica more milk was obtained with one milking per day and the cow raising her own calf than by two milkings without calf. These observations show the calf is probably most important for let-down in Bos taurus types.

On the other hand, Ngere et al. (1973) and Moulick et al. (1972) concluded the presence of the calf was mandatory for good milk production in the Hariana and Deshi herds, suggesting the calf serves to stimulate milk-letdown and improve temperament of the cows in the case of Zebu. The conclusion is that the calf serves to stimulate milk-let-down in all tropical breeds; therefore, differences among breeds for temperament would not be a strong consideration.

Estimated Dairy Merit. Using Tomar's (1965) equation, which incorporates age at first calving and calving interval, to estimate breeding efficiency, the Colombian breeds rated 18 to 20 points higher than either of the Indian breeds. If the calving interval and age at first calving of the Hariana equaled that of the $\mathrm{BON}$ or CCC (table 2), the number of dry cows and heifers over 36 months of age needed for a herd expected to yield a given volume of milk could be reduced more than $30 \%$. This is an attractive possibility but as pointed out by McDowell and McDaniel (1968) numerous traits are involved in determining the overall dairy merit of a group of cattle. Following the procedures recommended by McDowell (1972), average values derived for age at first calving, milk yield and viability were used to develop hypothetical herds that would be expected to provide a yield of $400 \mathrm{~kg}$ of milk per day throughout the year (table 5).

Average length of lactation was short in the $B O N$ and $C C C$, thus the ratio of dry to lactating cows was $4.2: 1$ for BON as compared to slightly less than a $1: 1$ ratio for Hariana. The inventories of young stock took into consideration the numbers needed to maintain both the dry and lactating cows based on the derived estimated cow losses per year, viability of young stock (table 4) and average age of first calving (table 2). Although the BON and

TABLE 5. NUMBERS OF FEMALES REQUIRED FOR A HERD THAT WILL PRODUCE 400 KG OF MILK PER DAY THROUGHOUT THE YEAR

\begin{tabular}{|c|c|c|c|c|c|c|}
\hline & \multirow{2}{*}{\multicolumn{4}{|c|}{ Pure Breeds }} & \multicolumn{2}{|c|}{ Crosses } \\
\hline & & & & & \multirow{2}{*}{ 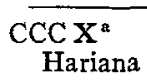 } & \multirow{2}{*}{$\begin{array}{l}\text { European }{ }^{b} \\
\text { X Hariana }\end{array}$} \\
\hline & Hariana & Deshi & $\mathrm{CCC}$ & $\mathrm{BON}$ & & \\
\hline No. lact. cows ${ }^{c}$ & 125 & 250 & 129 & 133 & 121 & 55 \\
\hline $\begin{array}{l}\text { No. dry cows } \\
\text { Young stock }^{\mathrm{d}}\end{array}$ & 99 & 145 & 196 & 563 & 120 & 20 \\
\hline$>36$ months & 44 & 74 & 72 & 161 & 22 & 0 \\
\hline 25 to 36 months & 48 & 81 & 79 & 177 & 30 & 17 \\
\hline 12 to 24 months & 53 & 89 & 87 & 195 & 57 & 18 \\
\hline$<12$ months & 64 & 107 & 104 & 234 & 69 & 23 \\
\hline Total number & 433 & 746 & 667 & 1463 & 419 & 134 \\
\hline
\end{tabular}

a Projected numbers based on approximately $10 \%$ heterosis for milk yield, length of lactation and viability and crosses have characteristics of $\mathrm{CCC}$ in age of first calving and calving interval.

humbers based on preliminary performance of $F_{1}$ crosses of Jersey, Brown Swiss and Holsteins with Hariana at Haringhata.

c No. lact. cows $=\frac{\text { proposed farm yield }}{\text { yield } / \text { cow/day }}$

a No. dry cows $=\frac{\% \text { time dry }}{\% \text { time in lactation }} \times$ no. lact. cows

- Young stock:

36 months $=$ (lact. + dry cows) $\mathrm{x}$ cow losses $/$ year $+10 \%$ to allow for losses after 36 months.

25 to 36 months $=$ no. in $>36$ months $+10 \%$

$<12$ months $=$ no. in 25 to 36 months $+20 \%$ (avg calf mortality) 
CCC excelled in length of calving interval, they were poor in persistency of lactation yield; consequently, larger numbers would be needed than for Hariana to provide the same daily output of milk. The Colombian breeds had no lactations that exceeded 300 days and the Deshi only a small percentage. More than $25 \%$ of the Hariana lactations exceeded 300 days; therefore, if the average for total days in milk had been used the Hariana numbers would be reduced to about 400 . If milk yield and other traits which affect total performance are taken into account, the Hariana appears superior to the other three breeds.

In table 5 are given the projected numbers for a $400 \mathrm{~kg}$ producing herd using the " $\mathrm{ex}$ pected performance" of CCC-Hariana $F_{1}$ crosses. The projected numbers were based on approximately $10 \%$ heterosis for milk yield, length of lactation and viability and the crosses having characteristics of CCC for age at first calving and calving interval. (Level of heterosis for traits other than reproduction were based on estimates of McDowell, 1972 and for reproduction, McDowell, Fletcher and Johnson, 1959). Theoretically the crosses would afford about $3 \%$ advantage in herd numbers over Hariana. In contrast, average performance at Haringhata, India of $F_{1}$ crosses of Brown Swiss, Holsteins and Jerseys with Hariana type cattle indicate crosses with these breeds would reduce herd numbers by $69 \%$ (table 5). The European-Hariana crosses can be milked without the calf present which has advantages (Moulick et al., 1972). Comparison of the two types of crosses suggests it would be more advantageous for the Indian cattleman to choose Bos taurus selected for milk yield, but possibly lacking in adaptation for tropical conditions, over Bos taurus types adapted to a tropical environment but unselected for milk yeild.

On the other hand, if the low milk yield of the Colombian breeds is due to incomplete milk-let-down in the absence of their calves, their performance for beef production might be superior to that of the Bos indicus breeds or, at least, they may prove useful in crossbreeding. Preliminary evidence suggests that these benefits may be worthwhile in herds of Bos indicus producing beef in Latin America (Stonaker, 1971).

It should also be pointed out that milk yields of BON and CCC are possibly poorer than for other Criollo types. The Central
American Criollo type found in certain areas of Venezuela and Costa Rica have shown yields of over $2,000 \mathrm{~kg}$ for cows milking 220 days or longer, calving intervals of less than 400 days and age of first calving less than three years (Bodisco and Mazzari, 1962; de Alba and Carrera, 1958; Rio and Bodisco, 1962). Currently the disadvantage of these Criollo for use elsewhere is the shortage of progeny tested sires for milk yield.

\section{Literature Cited}

Bodisco, V. and G. Mazzari. 1962. Eficiencia reproductiva de las vacas Criollos y pardo suizas en el Centro de Investigaciones Agronómicas, Maracay, Venezuela. Min. Agr. Cria, Venezuela Bol, Técn. No. 14.

Branton, C., R. E. McDowell and M. A. Brown. 1966. Zebu-European crossbreeding as a basis of dairy cattle improvement in the U.S.A. Sou. Coop. Series Bull. 114. La. Agr. Exp. Sta., Baton Rouge, La.

de Alba, J. and C. Carrera. 1958. Selección del ganado Criollo lechero tropical. Comm. Turrialba No. 61. Turrialba, Costa Rica.

Mahadevan, P. 1966. Breeding for Milk Production in Tropical Cattle. Commonwealth Agr. Bureaux. Tech. Comm. No. 17, Edinburgh.

McDowell, R. E., J. L. Fletcher and J. C. Johnson. 1959. Gestation length, birth weight and age at first calving of crossbred cattle with varying amounts of Red Sindhi and Jersey breeding. J. Anim. Sci. $18: 1430$.

McDowell, R. E. and B. T. McDaniel. 1968. Interbreed matings in dairy cattle. III. Economic aspects. J. Dairy Sci. 51:1.

McDowell, R. E. 1971. Feasibility of commercial dairying with cattle indigenous to the tropics. Cornell Inter. Agr. Dev. Bull. 21, Cornell Univ., Ithaca, N.Y.

McDowell, R. E. 1972. Improvement of Livestock Production in Warm Climates. W. H. Freeman, \& Co., San Francisco, Calif.

Miller, P., L. D. Van Vleck and C. R. Henderson. 1967. Relationships among herd life, milk production, and calving interval. J. Dairy Sci. 53:1283.

Moulick, S. K., R. E. McDowell, L. D. Van Vleck and H. Guha. 1972. Potential of Deshi cattle of India for dairy production. J. Dairy Sci. 55:1148.

Ngere, L. O., R. E. McDowell, S. Bhattacharya and H. Guha. 1973. Factors influencing milk yield of Hariana cattle. J. Anim. Sci. 36:457.

Pearson, L., R. K. Waugh, B. Salazar, F. M. Botero and O. Acosta. 1968. Milking performance of Blanco Orejinegro and Jersey crossbreds, J. Agr. Sci. 70:65.

Pearson, L. 1968. A note on the history of blackeared white cattle. Agr. History Rev. 16:(Part II) 159.

Pinzon, E., J. Corvantes, B. Salazar, R. Rubio y D. Melo. 1954. Bovinos Criollos Colombianos. D.I.A. Bol. Divulgacion 5, Bogota, D.E.

Plasse, D., B. Mueller-Haye, R. Gil, M. Koger, M. Butterworth and T. Linares. 1968. Preweaning performance of Criollo and Brahman calves and their 
reciprocal crosses. Proc. 2d World Conf. Anim. Prod. Bruce Pub. Co., St. Paul, Minn. p. 312.

Rios, C. E. and V. Bodisco. 1962. Pruebas de toros Criollos lecheros en el Centro de Investigaciones Agronómicas, Maracay, Venezuela. Min. Agr. Cria, Venezuela Bol. Técn. No. 15.

Salazar, J. J. and R. K. Waugh. 1968. Comparative milk production of native and European breeds and crosses under tropical conditions of Colombia. Proc. 2d World Conf. Anim. Prod., Bruce Pub. Co., St. Paul, Minn. p. 484.

Salazar, J. J., C. J. Wilcox, M. Koger, F. G. Martin and R. K. Waugh. 1970. Reproductive performance of three Colombian Holstein herds. J. Dairy Sci. $53: 673$.

Stonaker, H. H. 1971. Animal breeding in the tropics of Latin America. J. Anim. Sci. 33:1.

Tomar, N. S. 1965: A note on the method of working out breeding efficiency in Zebu cows and buffaloes. Indian Dairyman. 17:389.

Touchberry, R. W. 1967. A study of the N'Dama cattle at the Musaia Animal Husbandry Station in Sierra Leone. Univ. Illinois. AID Bull. No. 724, Urbana. 